\title{
Studies on Effect of Different Packaging Materials and Storage Temperature on Total Chlorophyll Content of Amaranthus (Amaranthus viridis)
}

\author{
M. S. Marichamy*, S. Harini, J. Jyothsna, V. Bhuvaneswari Devi, \\ B. Rajapriya, A. Rajalakshmi, and R. Ahaljith
}
Department of Horticulture, Pandit Jawaharlal Nehru College of Agriculture and Research Institute, Karaikal, U.T. of Puducherry, India

*Corresponding author

\section{A B S T R A C T}

\begin{tabular}{|c|}
\hline Keywords \\
\hline $\begin{array}{l}\text { Amaranthus, } \\
\text { Packaging } \\
\text { materials, Plastic } \\
\text { Crates, ZECC, } \\
\text { Ambient storage, } \\
\text { Total Chlorophyll } \\
\text { Content }\end{array}$ \\
\hline Article Info \\
\hline $\begin{array}{l}\text { Accepted: } \\
\text { 07 September } 2020 \\
\text { Available Online: } \\
10 \text { October } 2020\end{array}$ \\
\hline
\end{tabular}

\section{Introduction}

Amaranthus is the most common leafy vegetable grown during summer and rainy season in India. The fresh tender leaves and stem give delicious preparation on cooking. It belongs to the family Amaranthaceae. Among the leafy types, A. tricolour L. is the main cultivated species in India. Other cultivated
Amaranthus is the most important leafy vegetables inSouth India. It is an excellent source of calcium, magnesium, potassium, vitamin $C$, vitamin $B_{6}$, folate, vitamin $A$, and an incredible source of vitamin $\mathrm{K}$. The experiment was conducted to standardize the effect of different packaging materials and storage temperature on the chlorophyll content of Amaranthus. The present study, $100 \mathrm{~g}$ of freshly harvested, tender green leaves along with roots were weighed and packed in different packing materials viz., plastic crates, 200 and 300 gauge polyethylene bag without and 1 per cent perforation followed by stored under ambient storage $\left(25^{\circ} \mathrm{C} \pm 2^{\circ} \mathrm{C}\right.$ and $\left.50.33-73.66 \% \mathrm{RH}\right)$ and Zero Energy Cool Chamber at $22.36-24.73^{\circ} \mathrm{C}$ and $92.66-97.36 \% \mathrm{RH}$. The total chlorophyll content was recorded at 1 DAS, 2 DAS, 3 DAS, and 4 DAS (Days after Storage). In general, the total chlorophyll content of amaranthus gradually decreased as the storage period increased from 1 DAS to 4 DAS. Among the different treatments, the treatment $T_{1}$ (Amaranthus packed in 200 gauge polyethylene bag without perforation and stored under ZECC) which recorded maximum total chlorophyll content even end of the 4 DAS. It was followed by amaranthus packed in 200 gauge polyethylene bag with 1 per cent perforation and stored under ZECC) $\left(\mathrm{T}_{2}\right)$. While the minimum chlorophyll content was recorded in amaranthus packed in plastic crates and stored under ambient condition $\left(\mathrm{T}_{10}\right)$ 
in joint health and keeps skin looking beautiful. The folate in amaranth leaves decreases cardiovascular damage and also keeps the memory strong. The demand for amaranthus is increasing in India and outside the country during the offseason.

On account of the perishable nature of these vegetables, the trade faces definite postharvest problems. Post-harvest losses start from pre harvesting stage itself followed by harvesting, handling, cleaning, transportation, storage, packing, processing, and marketing. Though amaranthusis nutritious and fetches good returns, it suffers from a very poor shelf life because of the high amount of moisture content in the leaves.

The postharvest shelf life of amaranthus was one day at ambient room temperature. Therefore, there is a need to prolong the shelf life of the amaranthus for at least one week. With this background in view, the investigation was undertaken with the effect of packaging materials and storage temperature on the total chlorophyll content of amaranthus.

\section{Materials and Methods}

The lab experiment on storage studies on amaranthus was conducted in the Under Graduate laboratory of the Department of Horticulture, Pandit Jawaharlal Nehru College of Agriculture and Research Institute, Karaikal.

The amaranthus was raised under irrigated conditions by adopting the recommended package of practices. Twenty-five days after sowing the crop was ready for harvesting. Uniform, tender mature fresh greens were harvested along with stem during morning hours.

They were immediately brought to the laboratory then washed and surface dried leaves and used for this experiment. The experiment was laid out in a Completely Randomized Design (CRD) with ten treatments and replicated thrice.

The treatments comprising of viz., $\mathrm{T}_{1}$ : Amaranthus packed in 200 gauge polyethylene bag without perforation and stored under ZECC; $\mathrm{T}_{2}$ : Amaranthus packed in 200 gauge polyethylene bag with 1 per cent perforation and stored under ZECC; $\mathrm{T}_{3}$ : Amaranthus packed in 300 gauge polyethylene bag without perforation and stored under ZECC; $\mathrm{T}_{4}$ : Amaranthus packed in 300 gauge polyethylene bag with 1 per cent perforation and stored under ZECC; $\mathrm{T}_{5}$ : Amaranthus packed in plastic crates and stored under ZECC; $\mathrm{T}_{6}$ : Amaranthus packed in 200 gauge polyethylene bag without perforation and stored under ambient condition; $\mathrm{T}_{7}$ : Amaranthus packed in 200 gauge polyethylene bag with 1 per cent perforation and stored under ambient condition; $\mathrm{T}_{8}$ : Amaranthus packed in 300 gauge polyethylene bag without perforation and stored under ambient condition; $\mathrm{T}_{9}$ : Amaranthus packed in 300 gauge polyethylene bag with 1 per cent perforation and stored under ambient condition; $\mathrm{T}_{10}$ : Amaranthus packed in plastic crates and stored under ambient condition (Table 2).

The size of the polyethylene bag used was $45 \times 30 \mathrm{~cm}$. Perforation was provided by punching holes on both sides of the bag to the extent of 1 per cent perforation of the total surface area.

In the present study, $100 \mathrm{~g}$ of freshly harvested, tender green leaves along with roots were weighed and packed in different packing materials viz., plastic crates, 200 and 300 gauge without and 1 per cent perforation followed by ambient storage $\left(25^{\circ} \mathrm{C} \pm 2^{\circ} \mathrm{C}\right.$ and $50.33-73.66 \% \mathrm{RH})$ and Zero Energy Cool Chamber at $22.36-24.73^{\circ} \mathrm{C}$ and 92.66 $97.36 \% \mathrm{RH}$. 
The shelf life of the stored samples was studied by recording the total chlorophyll content of leaves for all the samples from $1^{\text {st }}$ day to $4^{\text {th }}$ day of storage (DAS). Total chlorophyll content was calculated by using the following formula and the mean was expressed as $\mathrm{mg} \mathrm{g}^{-1}$ (Yoshida et al., 1971).

$$
\text { Total chlorophyll }=\frac{\mathrm{A}_{652} \times 1000 \times \mathrm{V} \times 1}{34.5 \times 1000 \times \mathrm{W}}
$$

\section{Results and Discussion}

Effect of different packaging materials and storage temperature on Total chlorophyll content $(\mathrm{mg} / \mathrm{g})$

In general, the total chlorophyll content of amaranthus gradually decreased as the storage period increased from 1 DAS to 4 DAS (Table 1). In the present study, it was found that the treatment $T_{1}$ (Amaranthus packed in
200 gauge polyethylene bag without perforation and stored under ZECC) which recorded the maximum total chlorophyll content even end of the 4 DAS. It was followed by amaranthus packed in 200 gauge polyethylene bag with 1per cent perforation $\left(\mathrm{T}_{2}\right)$. While the highest physiological loss in weight and minimum total chlorophyll content was recorded in amaranthus packed in plastic crates and stored under ambient condition $\left(\mathrm{T}_{10}\right)$ and it was followed by the treatment $\mathrm{T}_{5}$ (Amaranthus packed in plastic crates and stored under ZECC) at the end of 4 DAS. This may be due to the reason that leaf yellowing as characterized by a decrease in total chlorophyll content was also accelerated by water stress. Total chlorophyll content was generally not stable, partly because of the tendency for leaves to lose water rapidly and decreasing total chlorophyll content upon leaf yellowing.

Table.1 Effect of different packaging materials and storage temperature on total chlorophyll content $(\mathrm{mg} / \mathrm{g})$ of amaranthus

\begin{tabular}{|c|c|c|c|c|}
\hline Treatments & 1 DAS* & 2 DAS & 3 DAS & 4 DAS \\
\hline $\mathbf{T}_{\mathbf{1}}$ & 4.10 & 4.03 & 2.76 & 2.15 \\
\hline $\mathbf{T}_{\mathbf{2}}$ & 3.65 & 2.81 & 2.46 & 1.94 \\
\hline $\mathbf{T}_{\mathbf{3}}$ & 3.00 & 2.06 & 2.06 & 1.72 \\
\hline $\mathbf{T}_{\mathbf{4}}$ & 2.60 & 1.99 & 1.52 & 1.32 \\
\hline $\mathbf{T}_{\mathbf{5}}$ & 1.40 & 1.32 & 1.16 & 1.02 \\
\hline $\mathbf{T}_{\mathbf{6}}$ & 3.03 & 2.31 & 2.07 & 1.82 \\
\hline $\mathbf{T}_{\mathbf{7}}$ & 2.62 & 2.05 & 1.84 & 1.52 \\
\hline $\mathbf{T}_{\mathbf{8}}$ & 1.62 & 1.53 & 1.25 & 1.24 \\
\hline $\mathbf{T}_{\mathbf{9}}$ & 1.48 & 1.40 & 1.17 & 1.09 \\
\hline $\mathbf{T}_{\mathbf{1 0}}$ & 1.31 & 1.28 & 0.99 & 0.93 \\
\hline $\mathbf{S E d}$ & $\mathbf{0 . 4 7 2 4}$ & $\mathbf{0 . 3 9 6 3}$ & $\mathbf{0 . 3 2 5 0}$ & $\mathbf{0 . 2 7 2 0}$ \\
\hline $\mathbf{C D}(\mathbf{0 . 0 0 5})$ & $\mathbf{0 . 9 8 5 4} * *$ & $\mathbf{0 . 8 2 6 6} * *$ & $\mathbf{0 . 6 7 8 0} * *$ & $\mathbf{0 . 5 6 7 5 * *}$ \\
\hline
\end{tabular}

* DAS - Days After Storage 
Table.2 Treatment details

\section{$T_{1}$ Amaranthus packed in 200 gauge polyethylene bag without perforation and stored under ZECC}

$\mathbf{T}_{\mathbf{2}}$ Amaranthus packed in 200 gauge polyethylene bag with 1 per cent perforation and stored under ZECC.

$\mathbf{T}_{3}$ Amaranthus packed in 300 gauge polyethylene bag without perforation and stored under ZECC.

T 4 Amaranthus packed in 300 gauge polyethylene bag with 1 per cent perforation and stored under ZECC.

$\mathbf{T}_{5}$ Amaranthus packed in plastic crates and stored under ZECC.

T6 Amaranthus packed in 200 gauge polyethylene bag without perforation and stored under ambient condition

$\mathbf{T}_{7}$ Amaranthus packed in 200 gauge polyethylene bag with 1 per cent perforation and stored under ambient condition

T. Amaranthus packed in 300 gauge polyethylene bag without perforation and stored under ambient condition

T9 Amaranthus packed in 300 gauge polyethylene bag with 1 per cent perforation and stored under ambient condition

T10 Amaranthus packed in plastic crates and stored under ambient condition.

The loss of greenness results in the loss of chlorophyll. The rate of loss depends greatly on temperature. Low temperature reduced the decrease in total chlorophyll content during the storage and the effect was more pronounced in non packed leaves than packed leaves and covering the leaves with a wet cloth (Lizan et al., 1987).

\section{References}

Lizan, H., Z.M. Ali, A. Mohd, and Nahar, F.
1987. Water stress and quality decline during storage of tropical leafy vegetables. Journal of Food Science and Technology, 52 (5): $1286-1288$.

Yoshida, S., D.A. Forno, J.H. Cook, and Gomez, K.A. 1971. Laboratory manual for physiological studies of rice. IRRI. The Philippines , pp. 43.

\section{How to cite this article:}

Marichamy, M. S., S. Harini, J. Jyothsna, V. Bhuvaneswari Devi, B. Rajapriya, A. Rajalakshmi, and Ahaljith, R. 2020. Studies on Effect of Different Packaging Materials and Storage Temperature on Total Chlorophyll Content of Amaranthus (Amaranthus viridis). Int.J.Curr.Microbiol.App.Sci. 9(10): 716-719. doi: https://doi.org/10.20546/ijcmas.2020.910.086 